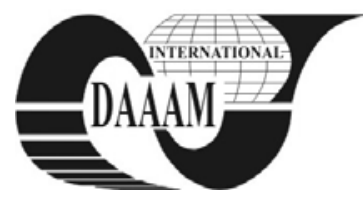

Annals of DAAAM for 2011 \& Proceedings of the 22nd International DAAAM Symposium, Volume 22, No. 1, ISSN 1726-9679 ISBN 978-3-901509-83-4, Editor B. Katalinic, Published by DAAAM International, Vienna, Austria, EU, 2011 Make Harmony between Technology and Nature, and Your Mind will Fly Free as a Bird

\title{
COMPARATIVE ANALYSIS OF CORPORATE GOVERNANCE SYSTEMS
}

\author{
BECIC, D[aliborka]
}

\begin{abstract}
Since the separation of ownership and managing function resulted in emergence of the corporations lots of corporate governance issues where raised. Therefore, this paper presents characteristics of corporate governance systems (Anglo-Saxon system and European system) and provides comparative analysis of each system. Contemporary corporate governance systems are moving towards convergence therefore it is important that the best practices from every system are applied in corporations
\end{abstract}

Key words: corporation, corporate governance, Anglo-Saxon system, European system

\section{INTRODUCTION}

An evolution of the companies and business throughout the long time period led to the separation of the ownership and managing function and resulted in emergence of corporations.

From the etymological point of view, word corporation origins from the Latin word "corpus" meaning body. Term "corpus" represents a group of people empowered to act as one. Monks and Minow define corporation as a "mechanism created in order to allow participation in capital, knowledge and work all directed to achieve maximum benefit for everybody (Monks \& Minow, 2001). Major characteristics of the corporation are its legal personality, limited liability of corporation's owners, ease of ownership change and perpetual life.

Since the separation of ownership and managing function resulted in emergence of the corporations lots of corporate governance issues where raised. Therefore, this paper presents characteristics of corporate governance systems and provides comparative analysis of each system.

\section{CHARACTERISTICS OF CORPORATE GOVERNANCE SYSTEM}

Corporate governance can be defined as a system of supervisory mechanisms used by all suppliers of crucial inputs in order to ensure returns on their investments in the corporation without jeopardizing corporation's prosperity (Tipurić, 2006). Corporate governance should provide answers on questions regarding who supervises the corporation and why (Kaen, 2003).

Corporate governance systems and the role of corporations' governing structures are very important for creating an effective corporate governance framework. Corporate governance systems are usually classified on the Anglo-Saxon corporate governance system and the Continental or European corporate governance system. Each system has its own characteristics and ways of functioning.

Corporate governance systems differ according to the most important stakeholders who influence the decision making process in corporations, as well as the instruments and mechanisms used by those stakeholders to affect the corporate governance process.
The Anglo-Saxon system is typical for Anglo-Saxon countries and is also known as the shareholder system. Large and liquid stock markets, low concentration of ownership, onetier board of directors, and relatively high level of protection for minority shareholders and dominant role of the institutional investors are basic characteristics of the Anglo-Saxon corporate governance system (Thomsen, 2003). Management is not controlled nor supervised by any of the corporation's stakeholder groups. Control over the management is performed by the stock market and investors.

The Continental or European corporate governance system is typical in the European countries and is also known as stakeholder system. This corporate governance system is opposed to the Anglo-Saxon corporate governance system. In the European system shareholder groups hold large percentage of the total number of shares that are publicly traded which ensures the owners of to decide on many of the problems concerning the corporation. Corporate ownership is concentrated and small number of investors, along with banks and employees has a significant impact on governing processes (Tipurić, 2008).

Corporate ownership is typically concentrated among a stable network of strategically oriented banks and other industrial companies. Consequently, the market for corporate control has a lower impact on management than in the AngloSaxon system.

Banks play the central external governance role through relational financing, providing financial services and monitoring in times of financial distress. Banks and industrial companies hold large blocks of shares in European corporations and actively participate in supervision and governing processes of the corporations. Block holders use their voting power to directly influence the way corporations are being governed and they rarely trade their shares (Jackson \& Moerke, 2005).

Concentrated ownership structure enables owners to maintain the control over the corporation and to make decisions that enhance the profitability of the corporation instead of enlarging the corporation's size through large investments.

Low ownership concentration is the main problem of Anglo-Saxon corporate governance system and also a reason why the management has a main role in this corporate governance system. In these conditions, managers make all the important business decisions that matter the corporation. Besides that, it is very hard to supervise or to discipline the management.

The management often makes decisions in their own interest which gives rise to over-investment. Managers prefer to enlarge the corporation because this enhances their power. Investments will thus be made even if the profitability is low or negative. Over-investment will thus give power to management, but leaves shareholders with a lower profitability because managers will invest even though profit prospects are poor (Ooghe \& Vuyst, 2001).

The most effective way of management control in the Anglo-Saxon corporate governance system is the market for corporate control. If the shareholders are not satisfied with the 
way management governs the corporation they will sell their shares. When large amount of shares is sold the price of single share is reducing and the corporation becomes a good target for hostile takeover. In case of hostile takeover the present management of the corporation is usually replaced with the new management (Tipurić et. al., 2009).

\section{COMPARISON OF CORPORATE GOVERNANCE SYSTEMS}

Comparative analysis of the systems of corporate governance has partially overcome initial focus on AngloAmerican systems, usually covering the issues such as ownership configurations, acquisition of capital, legal regulation (e.g. company and employment law) and the corresponding distribution of power within the corporation (Roe, 1993; Charkham, 1994; Scott, 1997; La Porta et al., 1997; La Porta et al., 1999).

Despite some arguments favouring common-law systems as facilitators of growth of capital markets due to better investor protections (in terms of character of legal rules and quality of law enforcement) (La Porta et al., 1997), there are few reasons to inherently prefer any system (Choi et al., 1999).

Economic performance does not seem to be intrinsically related to governance systems. The effectiveness of any system can be analysed in terms of processes (e.g. levels of transparency and accountability of managers and firms to particular stakeholders) and economic, social and environmental outcomes.

When it comes to accountability, systems also differ in terms of dominant forms - in particular in terms of relative weight they give to private and public accountability of companies. Depending on circumstances encountered by stakeholders, these differences may occasionally imply different aggregate levels of accountability.

Globalization of business operations and financial markets, coupled with complementary political processes (e.g. integration and expansion of the European Union, formation of regional free trade associations and the World Trade Organization etc.), has spurred the interest in corporate governance (seen primarily as a means of securing investors' claims) and the debate about the convergence of corporate governance systems.

The requirements for increased transparency and consistency of governance practices across systems have been favoring a more widespread application of arms-length mechanisms, historically prevalent in Anglo-American systems of corporate governance, which have been endorsed by the current global standard (OECD, 1999).

What should not be overlooked is that these elements are superimposed on the existing structure of legal and habitual instruments, which may not be entirely consistent with them; any re-institutionalization in that case is gradual. If the new regulations related to corporate or national governance (sometimes labeled 'best practice') are adopted without sufficient legitimacy and/or leeway for adaptation to specific circumstances, the risk of non-compliance increases.

On the other hand, increased complexity and interconnectedness of business operations and increasing importance of relational aspects of business redefine the corporation and its accountability processes. The corporation becomes a flexible bundle of tangible and intangible resources, competences and relationships with shifting boundaries with the environment.

The differentiation aimed at matching increased environmental demands requires a balance by the redefined integrating forces within the organization. Since the processes of acquisition, development and reproduction of these resources increasingly involve a wider web of stakeholders, the governance processes related to these resources become increasingly complex.

\section{CONCLUSION}

When comparing corporate governance systems it cannot be said that one system is better than other one. Contemporary corporate governance systems move towards convergence and it is important that the best practices from every system are applied in corporations.

Governments should create a legal framework in which corporations would have to obey by certain legislation acts and not only to comply with recommendations or explain why those recommendations about best corporate governance practices where not applied.

\section{REFERENCES}

Charkham, J. (1994). Keeping Good Company: A Study of Corporate Governance in Five Countries, Oxford University Press, ISBN: 0198289871, Oxford

Choi, C.J.; Raman, M.; Usoltseva, O. \& Lee, S.H. (1999). Political Embeddedness in the New Triad: Implications for Emerging Economies. Management International Review, Vol. 39, No. 3, pp. 257-275, ISSN: 0938-8249

Jackson, G. \& Moerke, A. (2005). Continuity and change in corporate governance: comparing Germany and Japan. Corporate Governance, Vol. 13, No. 3, pp. 351-361, ISSN: 1472-0701

Kaen, F. R. (2003). A blueprint for corporate governance: strategy, accountability and preservation of shareholder value, American Management Association, ISBN: 081440586X, New York

La Porta, R.; Lopez-De-Silanes, F. \& Shleifer, A. (1999). Corporate Ownership Around the World. The Journal of Finance, Vol. 54, No. 2, pp. 471-517, ISSN: 0022-1082

La Porta, R., Lopez-De-Silanes, F. Shleifer, A. and Vishny, R.W. (1997). Legal Determinants of External Finance. The Journal of Finance, Vol. 52, No. 3, pp. 1131-1150, ISSN: 0022-1082

Monks, R. A. \& Minow, N. (2001). Corporate Governance, 2nd ed, Blackwell Publishers, ISBN: 0761924426, Oxford

OECD (1999). Principles of Corporate Governance, Available from: www.oecd.org Accessed: 2011-07-10

Ooghe, H. \& Vuyst, V. D. (2001). The Anglo-Saxon versus continental European corporate governance model: empirical evidence of board composition in Belgium, Available from: http://www.vlerick.com/en/5786VLK/version/default/part/AttachmentData/data/vlgms-wp2001-06.pdf Accessed: 2011-06-18

Roe, M. (1993). Some Differences in Corporate Structure in Germany, Japan and the United States. Yale Law Journal, Vol. 102, No. 8, pp. 1927-2003, ISSN: 0044-0094

Scott, J. (1997). Capitalist Business and the Corporate Classes, Oxford University Press, ISBN: 0198280769, Oxford

Thomsen, S. (2003). The convergence of corporate governance systems to European and Anglo-American standards: introduction. European Business Organization Law Review, Vol. 4, No. 1, pp. 31-50, ISSN: 1566-7529

Tipurić, D. (2006). Nadzorni odbor i korporativno upravljanje, Sinergija, ISBN: 953- 6895-30-7, Zagreb

Tipurić, D. (2008). Korporativno upravljanje, Sinergija, ISBN: 953-6895-07-02, Zagreb

Tipurić, D.; Tušek, B. \& Filipović, D. (2009). Internal and External Supervisory Mechanisms in Corporate Governance. South East European Journal of Economics and Business, Vol. 4, No. 2, pp. 57-70, ISSN: 1840-118X 